\title{
Densidade Linear do Sistema de Fibras Elásticicas dos Ligamentos Patelar, Cruzado Anterior e Cruzado Posterior
}

\author{
Linear Density of the Elastic Fibers System in Patellar and Cruciate Ligaments
}

Jose Ricardo Pecora ${ }^{1}$, Consuelo Junqueira Rodrigues ${ }^{2}$, Aldo Junqueira Rodrigues Jr. ${ }^{2}$, Osny Salomäo ${ }^{1}$

\begin{abstract}
RESUMO
Com o objetivo de comparar os ligamentos cruzados da articulação do joelho com o ligamento patelar, os autores realizaram análise da quantidade de fibras elásticas entre esses ligamentos por meio de amostras obtidas de sete cadáveres. O estudo histomorfométrico do sistema de fibras elásticas revelado por métodos seletivos de coloração mostrou não haver diferença na densidade linear de todo o sistema de fibras elásticas. Não foi observada diferença estatisticamente significante na quantidade de fibras elásticas maduras entre os três ligamentos estudados. Entretanto, a quantidade de fibras elásticas maduras e elaunínicas, fibras responsáveis pela elasticidade, foi maior no ligamento cruzado anterior. Dessa forma podemos inferir que o ligamento cruzado posterior e o ligamento patelar têm mais fibras oxitalânicas, que são responsáveis pela resistência tecidual. Os autores concluiram que o ligamento cruzado posterior e o ligamento patelar têm estrutura semelhante e parecem mais relacionados à transmissão de força, enquanto o ligamento cruzado anterior está relacionado à elasticidade da articulação de joelho.
\end{abstract}

\section{SUMMARY}

In order to verify the improvement to choose the better ligament that may be used in knee surgical repair, we performed a comparative analysis of the amount of the elastic fibers system between the patellar and cruciates ligaments. Samples of these ligaments obtained from seven human corpses were studied. Histomorphometric study of the elastic fibers, stained by selective methods didn't show differences in the total amount of all types of elastic fibers, in all three ligaments studied. No difference either was found in the amount of mature elastic fibers. However, the amount of mature and elaunin elastic fibers was significantly different. The anterior cruciate ligament had a greater amount of mature and elaunin elastic fibers, responsible for elasticity. So, the posterior cruciate and the patellar ligaments have more oxytalan elastic fibers, responsible for resistance. We concluded that the posterior cruciate and the patellar ligaments have similar structure and seem more related to transmittance of force, whereas the anterior cruciate ligament is related to elasticity of the knee joint.
Dos Departamentos de Ortopedia e Traumatologia ${ }^{1}$ e de Cirurgia², Faculdade de Medicina, Universidade de São Paulo. SP, Brasil

Endereço: Aldo Junqueira Rodrigues Junior, Faculdade de Medicina da USP, Disc.Topografia Estrutural Humana, Av. Dr. Arnaldo, 455, sala 1604. São Paulo, SP, Brasil. CEP 01246-903. Estrutural Humana, Av.
Fax 055-11-852 4877
From Departments of Orthopedics and Traumatology ${ }^{1}$ and of Surgery ${ }^{2}$, Faculty of Medicine University of Sao Paulo. Sao Paulo, Brazil

Address for reprint requests: Aldo Junqueira Rodrigues Junior. Faculdade de Medicina da USP Disc. Topografia Estrutural Humana. Av. Dr. Arnaldo 455, sala 1304. São Paulo, SP, Brasil. CEP 01246-903. Fax 055-11-852 4877 


\section{INTRODUÇÃO}

As rupturas traumáticas dos ligamentos cruzados anterior e posterior são comuns e potencialmente sérias, por provocarem sintomas incapacitantes para o paciente e acarretar lesões degenerativas na cartilagem articular e nos meniscos do joelho, culminando com a aceleração do processo de artrose. A reparação cirúrgica primária desses ligamentos não leva a bons resultados devido à sua arquitetura complexa, as demandas mecânicas durante os movimentos do joelho e a um ambiente intra-articular biologicamente agressivo. Devido aos maus resultados das reparações ligamentares, várias estruturas são utilizadas como enxerto para a reconstrução desses ligamentos. O terço central do ligamento patelar é o enxerto mais freqüentemente utilizado na reconstrução dos ligamentos cruzados anterior e posterior. Vários estudos usaram testes mecânicos para comparar a resistência e elasticidade dos ligamentos patelar e dos cruzados anterior e posterior. Porém, apesar do conhecimento da composição estrutural desses ligamentos, nenhum estudo comparativo do sistema fibroso elástico deles parece ter sido referido na literatura.

De acordo com Frank et al. ${ }^{(6)}$ (1985), os ligamentos têm estrutura semelhante, com variações leves em celularidade e vascularização, que dependem do tamanho, função e atividade metabólica. Todos estão basicamente compostos de feixes múltiplos de fibras de colágeno, com organização um ao outro ao longo do eixo do ligamento. Dois terços dos ligamento estão compostos de água e o peso seco está composto de colágeno (75\%), elastina (4,5\%), glicosaminoglicanas $(0,5 \%)$ e outras substâncias (20\%).

As fibras elásticas, responsáveis pela elasticidade dos tecido, foram estudadas em vários tecidos em condições normal e patológica, como no disco intervertebral (2), na cápsula articular do quadril ${ }^{(11)}$, na fáscia transversalis ${ }^{(18)}$, no ligamento transversal do atlas ${ }^{(20)}$

O sistema de fibras elásticas é composto por três tipos de fibras ligadas ao fenômeno da elastogênese. O primeiro componente formado durante elastogênese é a fibra oxitalânica, formada por microfibrilas sintetizadas e secretadas pelos fibrablastos no meio extracelular. Essas microfibrilas estão dispostas em feixes paralelos, indicando a direção e a forma da futura fibra elástica. Em seguida, pequena quantidade da substância amorfa, elastina, adere-se a essas microfibrilas, formando o segundo componente do sistema elástico: a fibra elaunínica. Com o acúmulo de maior quantidade de elastina entre as microfibrilas, a fibra se torna espessa, formandose o terceiro componente do sistema elástico: as fibras elásticas maduras. A presença dos três componentes do sistema de fibras elásticas dos tecidos indica uma elastogênese adequada. As fibras oxitalânicas dão resistência aos tecidos, enquanto que as fibras contendo elastina proporcionam elasticidade ${ }^{(8,19)}$. A quantidade dos

\section{INTRODUCTION}

Traumatic rupture of the anterior and posterior cruciate ligaments are common and potentially serious, since they can cause incapacitating symptoms and lead to degenerative lesions in the joint cartilage and in the menisci of the knee. Sometimes, culminating with acceleration of the process of arthrosis. The healing of these ligaments is quite difficult, even with primary reconstruction surgery, due to their complex architecture, their mechanical demands during the knee movement, and to the biologically aggressive intra-articular environment. Due to this difficult healing, various other structures have been utilized as grafts for the reconstruction of such ligaments, once rupture has occurred. The central third of the patellar ligament has frequently been used for such reconstruction of both anterior and posterior cruciate ligaments. Various studies have used functional tests to compare the resistance and elasticity of the patellar ligament with that of the anterior and posterior ligament. However, despite the knowledge of the structural composition of these ligaments, no comparative studies of the elastic fibrous system of these ligaments seem to have been reported in the literature.

According to Frank et al. ${ }^{(6)}$, the various ligaments have a similar microstructure, with slight variations in cellularity and vascularity that depend on size, function and metabolic activity. All are basically composed of multiple bundles of collagen fibers, arranged parallel to each other along the axis of the ligament. Two-thirds of the ligaments are composed of water, and the dry weight is composed of collagen (75\%), elastin (4.5\%), glycosaminoglycans (0.5\%) and other biochemical substances (20\%).

The elastic fibers, responsible for tissue elasticity, have been studied in various tissues both in normal and disease condition. In the musculoskeletal system, certain anatomical structures have been subject to special focus, including the intervertebral disc (2), the hip joint capsule ${ }^{(11)}$, the fascia transversalis ${ }^{(18)}$, the alar and transverse ligaments of the atlas (20).

The elastic fibers system consists of three types of fibers linked by the phenomenon of elastogenesis. The first component formed during elastogenesis is the oxytalan fiber, composed of microfibrils synthesized and secreted by fibroblasts in the extracellular environment. These microfibrils are arranged in parallel bundles, indicating form and direction of the future elastic fiber. Later, small portions of an amorphous substance, elastin, adhere to these microfibrils, giving rise to the second component of the elastic system: the elaunin fiber. With accumulation of a larger quantity of elastin between microfibrils, the fiber becomes thicker, forming the third component of the system: mature elastic fiber. Oxytalan fibers provide resistance, while fibers containing elastin supply elasticity ${ }^{(8,19)}$. The quantity of the three types of fibers varies in 
três tipos de fibras varia nos diferentes tecidos e parece depender da função e do processo de envelhecimento ${ }^{(17,18)}$

No presente estudo quantificamos o sistema de fibras elásticas nos ligamentos patelar e cruzados anterior e posterior, por meio de método histomorfométrico.

\section{MATERIAL E MÉTODOS}

Pequenas amostras retangulares da porção central dos ligamentos patelar (LP), cruzado anterior (LCA) e cruzado posterior (LCP) foram obtidas de joelhos de sete cadáveres adultos masculinos com idade variando de 20 a 40 anos. Estas amostras foram fixadas em formalina a $10 \%$, embebidas em parafina e submetidas a cortes seriados de $5 \mathrm{~mm}$ de espessura.

\section{Procedimento de coloração}

Os cortes histológicos foram submetidos aos três métodos de coloração específicos para fibras elásticas: hematoxilina férrica de Verhöeff, que evidencia as fibras elásticas maduras; o método resorcina-fucsina de Weigert, que evidencia fibras maduras e fibras elaunínicas; método de Weigert, com oxidação prévia com oxona como descrito previamente ${ }^{(7)}$, que revela os três tipos de fibras elásticas: maduras, elaunínicas e oxitalânicas.

\section{Avaliação morfométrica}

A densidade linear (LV) do sistema de fibras elásticas foi determinado em 25 campos microscópicos aleatórios por corte histológico corados pelos métodos de Verhöeff $(V)$, Weigert $(W)$ e Weigert-oxona (WO). Os cortes histológicos foram analisados sob microscopia óptica com uma ampliação de 1.000x, empregandose uma ocular com gratículo de integração exibindo 10 linhas paralelas contendo 100 pontos, apresentando uma área conhecida de $10.500 \mathrm{~m}^{2}$. Cada cruzamento do sistema de fibras elásticas que cruza com as lihas do gratículo foi contada. Essas interseções das fibras com o gratículo estão relacionadas com o comprimento das fibras por unidade de área, pela expressão LV $=2 \times \mathrm{Na}$, em que Na corresponde a comprimento da fibra por unidade de área (16). $A$ área de tecido examinada foi determinada pela contagem dos números de interseção dentro daquele tecido.

\section{Análise estatística}

Estatística descritiva (média, desvio-padrão e erro padrão da média) foi usada para comparar a densidade linear do sistema de fibras elásticas do LP, LCA e LCP. Análise de variância (ANOVA) foi usada para comparar os grupos ordinais paramétricos. As diferenças significantes foram discriminadas usando o teste de Tukey. Adotou-se o nível de significância de 5\% $(\mathrm{a}=0,05)$ para todas as análises. As diferenças significantes foram assinaladas com um asterisco e calculou-se o diferencial relativo (r\%). different tissues and seems to depend on both function and the aging process ${ }^{(17,18)}$.

In the present study we analyzed the amount of elastic fibers in the patellar, anterior and posterior cruciate ligaments, by using the histomorphometric method.

\section{MATERIAL AND METHODS}

Small rectangular samples of the central portion of the patellar $(P L)$, anterior cruciate (ACL), and posterior cruciate (PCL) ligaments in the right knee were obtained from seven cadavers of male adults, varying in age from 20 to 40 years. These samples were fixed with $10 \%$ formalin, embedded in paraffin, and submitted to serial sections of $5 \mathrm{~mm}$ of thickness.

\section{Staining procedure}

Three adjacent sections were submitted to one of the following selective methods for staining elastic fibers: Verhoeff's iodine-iron hematoxylin method, which evidenced only the mature elastic fibers; Weigert's resorcin-fuchsin, which stained mature and elaunin elastic fibers; Weigert's technique, with a previous oxidation performed using oxone as previously described (7), which stained the oxytalan, elaunin and mature elastic fibers.

\section{Morphometric evaluation}

Linear density (LV) of the elastic fiber system was determined in 25 random microscopic fields per histologic section stained by Verhoeff (V), Weigert (W) and Weigert-oxone (WO). Sections were scanned randomly at a magnification of 1,000x in a continuous line from edge to edge, employing a test eyepiece reticule with 10 parallel lines and 100 points which contains a simple square lattice test system with $10,500 \mathrm{~mm}^{2}$. Each elastic fiber completely intersected by any one of the test lines was counted. These intersections of fibers with a test reticule are related to the length of those fibers per unit of area, by the expression $\mathrm{LV}=2 \mathrm{Na}$, where $\mathrm{Na}$ is the length of fiber per unit of area ${ }^{(16)}$. Area of the tissue examined was determined by counting the number of points of intersection inside that tissue.

\section{Statistical analysis}

Descriptive statistics (average, standard deviation and standard error of the mean) were used to compare the linear density of the elastic fibrous system of PL, ACL and PCL. An analysis of variance (ANOVA) was used to compare the parametric ordinary groups. Significant differences were identified using the Tukey test. A level of significance of $5 \%$ was adopted $(a=0.05)$ for all analyses. 


\section{RESULTADOS}

Os ligamentos do joelho são constituídos por fascículos de fibras colágenas, densamente agrupadas, entremeadas por fibras elásticas e estruturas vasculares. Os feixes de fibras colágenas mostram uma disposição longitudinal ao maior eixo dos ligamentos, com as fibras elásticas dispostas de maneira paralela às colágenas. (fig. 1)

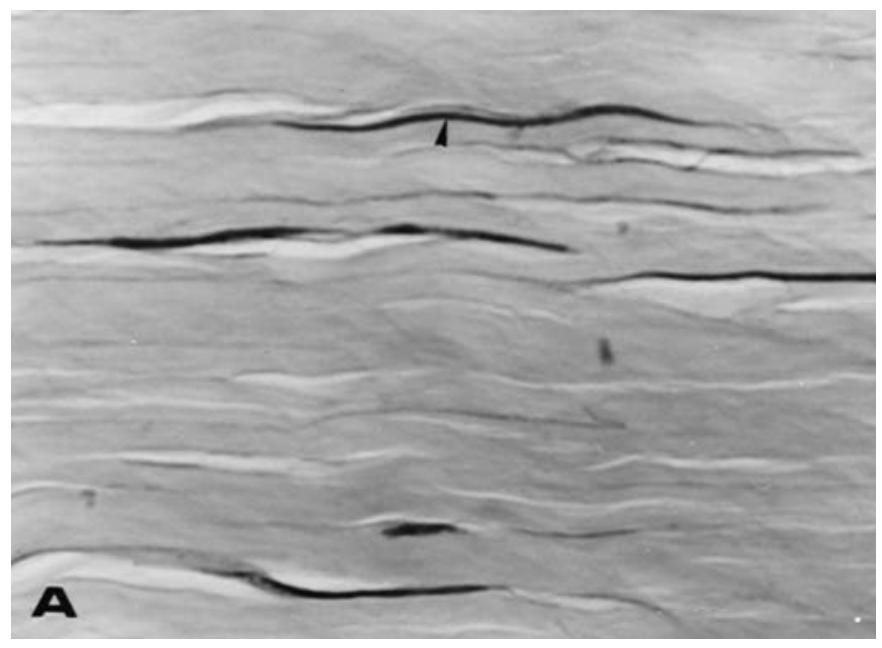

\section{RESULTS}

Knee ligaments were composed by dense bundles of collagen fibers intermingled with elastic fibers and vascular structures. Collagen fibers showed a longitudinal arrangement along the major axis of the ligaments, and elastic fibers runned parallel to the collagen ones (fig. 1).
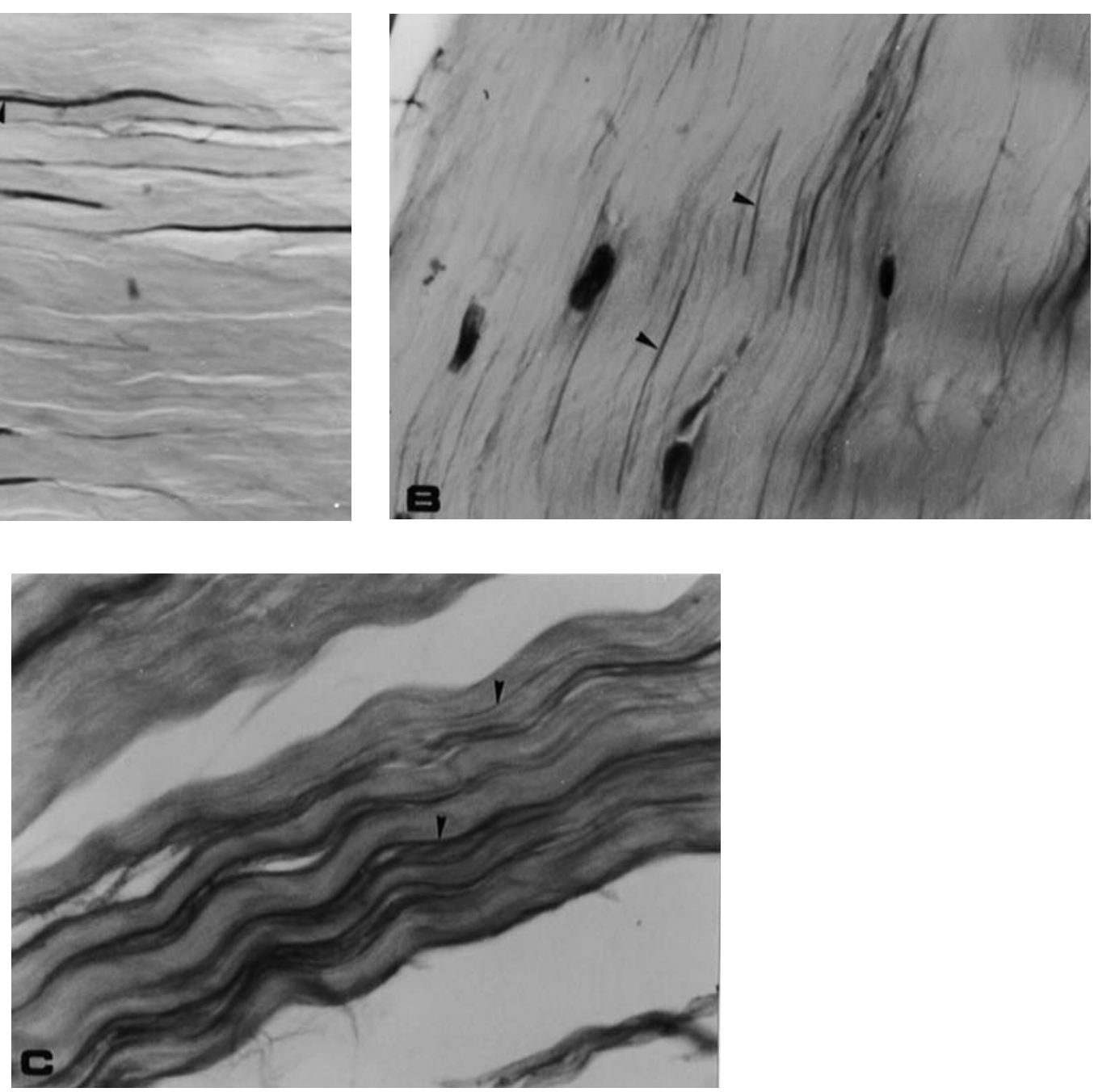

Fig. 1 - Fibras elásticas (setas) coradas por métodos seletivos. A - Ligamento cruzado posterior corado pelo método de Verhöeff(X600) $B$ - Ligamento cruzado anterior corado pelo mëtodo de Weiger(X600) C - Ligamento patelar corado pelo método Weigert-oxona(X600)

Figure 1. Elastic fibers (arrowhead) stained by selective methods. A - Posterior cruciate ligament stained by Verhoeff (X600) $B$ - Anterior cruciate ligament stained by Weigert (X600) C - Patellar ligament stained by Weigert-oxone (X600) 
Os valores da densidade linear (LV) do sistema de fibras elásticas no LP, LCA e LCP observados nos métodos de Verhöeff ( $V$ ), Weigert (W) e Weigert-oxona (WO) encontram-se nas tabelas 1.

A análise de variância da LWWO, que corresponde à quantidade de fibras elásticas maduras, oxitalânicas e elaunínicas não demonstrou diferenças significantes entre os três ligamentos estudados ( $F=3,27 ; p=0,05)$. O mesmo foi demonstrado para LW que corresponde à quantidade de fibras elásticas maduras $(F=$ $1,49 ; p>0,05)$. Os valores da LWW, que corresponde a quantidade de fibras maduras e elaunínicas mostram diferenças significantes ( $F=17,83 ; p<0,0001)$. O teste de Tukey mostra que os LWW do LCA são estatisticamente superiores aos do LP e LCP. O LVW dos dois últimos ligamentos não mostraram diferenças.

Desde que a análise estatística não mostrou nenhuma diferença entre os três tipos de ligamentos em relação à soma dos componentes do sistema elástico (fibras oxitalânicas, elaunínicas e maduras), nem em relação a fibras maduras, as diferenças estão somente na quantidade de fibras elaunínicas e oxitalânicas que estão inversamente relacionados. Assim, o LCA mostrou 88,5\% e $61,61 \%$ mais fibras elaunínicas que o LP e o LCP respectivamente. Este dois ligamentos têm proporcionalmente maior quantidade de fibras oxitalânicas que o LCA (fig. 2).

Fig. 2 - Quantidade relativa de fibras elásticas ( $M=$ maduras, $E=$ elaunínicas, e $\mathrm{O}=$ oxitalânicas) do ligamento patelar (PL), cruzado anterior (ACL) e cruzado posterior (PCL).
Linear density (LV) values of the elastic fibers in PL, ACL and PCL observed in Verhöeff (V), Weigert (W) and Weigert-Oxona (WO) stains were presented in tables 1.

Analysis of variance for LVWO, which corresponds to the amount of mature, elaunin and oxytalan elastic fibers, didnt't show significant differences between all three knee ligaments studied ( $F$ $=3.27 ; p>0.05)$. The same was shown for $L W$, which corresponds to the amount of mature elastic fibers $(F=1.49 ; p>0.05)$. Values of LVW that represent the amount of mature and elaunin elastic fibers showed significant differences ( $F=17.83 ; p<0.0001)$. The Tukey test showed that LVW of ACL was statistically higher in relation to $P L$ and $P C L$. The $L V W$ of the latter two ligaments was statistically the same.

Since the statistical analysis showed no differences among the three types of ligaments in relation to the sum of the components of the elastic system (oxytalan, elaunin, and mature elastic fibers), nor in relation to mature fibers, the differences are only in the amount of elaunin and oxytalan fibers, which are inversely related. Thus, the ACL showed $88.5 \%$ of elaunin fibers, while PL and PCL showed $61.61 \%$. These latter two ligaments have proportionally greater amount of oxytalan fibers than the ACL (fig. 2).

Figure 2. Relative quantity of elastic fibers ( $M=$ mature, $E=$ elaunin, and $\mathrm{O}=$ oxytalan) of the patellar (PL), anterior cruciate (ACL), and posterior cruciate $(P C L)$ ligaments.
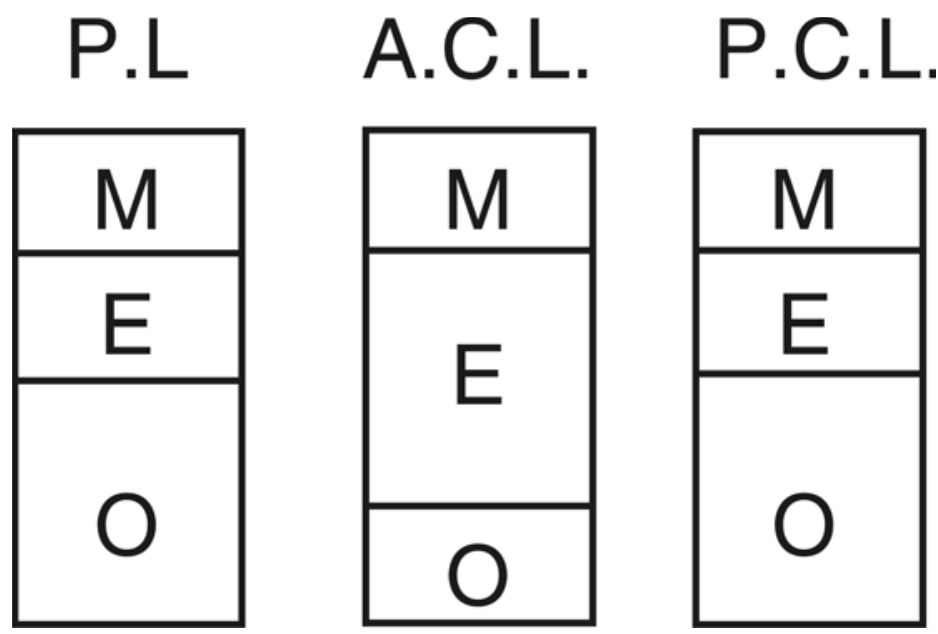
TABELA 1. Valores da Densidade Linear (LV) do sistema de fibras elásticas dos ligamentos patelar (LP). cruzado anterior (LCA), e cruzado posterior (LCP) observados nas colorações de Verhöff (V), Weigert (W) e Weigert-oxona (WO)
TABLE 1. Linear Density (LV) values of elastic fibers system of the patellar (PL), anterior cruciate (ACL), and posterior cruciate (PCL) ligaments observed in Verhöeff (V), Weigert (W) and Weigert-Oxona (WO) histological stains.

\begin{tabular}{cccc} 
Ligament & $\operatorname{LVWO}\left(\mu \mathrm{m}^{-2}\right)$ & $\mathrm{LVW}\left(\mu \mathrm{m}^{-2}\right)$ & $\operatorname{LVV}\left(\mu \mathrm{m}^{-2}\right)$ \\
\hline $\mathrm{PL}$ & $0.0119 \pm 0.0021$ & $0.0058 \pm 0.0023$ & $0.0091 \pm 0.0021$ \\
$\mathrm{ACL}$ & $0.0138 \pm 0.0029$ & $0.0109 \pm 0.0014$ & $0.0116 \pm 0.0025$ \\
\hline $\mathrm{PCL}$ & $0.0116 \pm 0.0021$ & $0.0068 \pm 0.0012$ & $0.0089 \pm 0.0019$ \\
& $\mathrm{NS}$ & $\mathrm{p}<0.001$ & $\mathrm{NS}$
\end{tabular}

\section{DISCUSSÃO}

O uso do terço central do LP como enxerto na reconstrução do LCA foi concebido por Jones ${ }^{(12)}$ e difundido por Clancy ${ }^{(4)}$, que estendeu seu uso para a reconstrução de LCP. Este procedimento tem sido utlizado por grande número de ortopedistas, para o tratamento cirúrgico de pacientes com lesões do LCA e do LCP.

O estudo destes ligamentos restringem-se ao exame das suas propriedades mecânicas ${ }^{(13)}$, porém são poucos os trabalhos sobre sua composição, especialmente em relação ao sistema de fibras elásticas do tecido conjuntivo(1,5,15).

A restrição do material desse estudo a cadáveres do sexo masculino entre 20 a 40 anos deve-se ao fato de que é nessa faixa etária que se encontra maior incidência de ruptura traumática do LCA e LCP.

O estudo estatístico dos resultados da densidade linear do LP, LCA e LCP para os três tipos de coloração histológica nos permite concluir que o LCA tem maior quantidade de elementos fibrosos do sistema elástico portadores de elastina que os outros ligamentos estudados. Estes resultados estão de acordo com os achados de Neurath et al. ${ }^{(15)}$, que compararam a quantidade de fibras do sistema elástico portadoras de elastina apenas entre o LCA e o LCP. Esses pesquisadores encontraram uma quantidade muito maior dessas fibras no LCA que no LCP. Nossos resultados sugerem que o LCA é mais elástico que tanto o LP quanto o LCP, devido à maior quantidade de fibras elaunínicas.

Forças mecânicas ativas influenciam o processo de elastogênese. O número e o arranjo das fibras do sistema elástico em uma estrutura dependem da função(8). Assim, proporção dos componentes do

\section{DISCUSSION}

The use of the central third of the $P L$ as a graft in the reconstruction of ACL was conceived by Jones ${ }^{(12)}$ and made popular by Clancy (4), who extended its use to the reconstruction of PCL as well. This procedure has been used by a large number of orthopedists for the surgical treatment of patients whose knees evidence a symptomatic deficiency of this ligaments, whether of the ACL or of the PCL.

Studies of these ligaments have been restricted to examination of the mechanical properties ${ }^{(13)}$, although a few papers have focused on the composition, especially in relation to the system of elastic fibers in the connective tissue ${ }^{(1,5,15)}$.

This study of knee ligaments was done in male cadavers between 20 to 40 years, because the greater incidence of traumatic rupture of the $A C L$ and PCL are most frequent in similar kind of persons.

Statistical analysis of results of the linear density of $P L, A C L$ and PCL for the three types of histological staining leads us to the conclusion that the ACL has a greater quantity of elastin-containing elements than do the other knee ligaments. These results agree with those of Neurath et al. ${ }^{(15)}$, who compared the quantity of elastincontaining fibers between the ACL and PCL. These researchers found the amount of such fibers to be greater in the ACL than in the PCL. The present results suggest that the ACL is more elastic than either the $P L$ or the $P C L$, due to the greater quantity of elaunin fibers.

Active mechanical force is involved in the process of elastogenesis. Number and arrangement of the fibers of the elastic system present in a structure depend on the function ${ }^{(8)}$. Thus, the proportion of the components of the elastic fibers system in the PL, ACL and PCL is intimately linked to the function of these anatomical structures. It 
sistema de fibras elástico no LP, LCA e LCP está intimamente ligado à função destas estruturas. Com a ressalva de que a resistência total e elasticidade de um ligamento não dependem somente da quantidade de elementos fibrosos elásticos em relação a fibras de colágenas, mas também do arranjo espacial destas fibras e do tamanho e espessura do ligamento como um todo, os resultados desse estudo parecem estar de acordo com o que se espera para a função dos três ligamentos estudados. O LP, como parte distal do mecanismo extensor do joelho, tem como função transmitir toda a força de tração do quadríceps, recebida pela patela, para a tuberosidade anterior da tíbia. Portanto, quanto menor a sua elasticidade, maior sua eficiência na transmissão de força de tração do quadríceps. O LCP é considerado o estabilizador posterior primário do joelho e o estabilizador básico do joelho, devido a sua proximidade com o centro de rotação ${ }^{(3,9)}$. Para desempenhar esta função, não pode ser alongado em excesso, justificando os nossos achados de uma quantidade menor de componentes fibrosos que contêm elastina em relação ao LCA.

O LCA é tensionado com a contração do quadríceps, na hiperextensão do joelho e aos movimentos de rotação interna e externa da tíbia em relação ao fêmur. na hiperextensão do joelho e movimentos de rotação interna e externa da tíbia em relação ao fêmur ${ }^{(14)}$. Percebe-se que o LCA tem um comportamento ativo, alongando-se e retraindo-se com o movimento anterior da tíbia em relação ao fêmur que ocorre com a contração do quadríceps na extensão do joelho. Ele age também como dissipador das forças rotacionais a que o joelho é submetido. Para desempenhar com eficiência estas funções, é necessário que possua uma elasticidade adequada, conferida por uma maior quantidade de elementos fibrosos portadores de elastina. Pode-se imaginar que quanto mais próximo da composição da estrutura a ser substituída pelo enxerto, mais eficiente será o enxerto. Portanto, em relação às fibras elásticas o LP seria um melhor substituto do LCP do que do LCA.

A maior elasticidade do LCA pode explicar por que sua ruptura compromete todo o arranjo dos feixes de fibras colágenas, reduzindo a sua capacidade de cicatrização, sendo neste caso uma indicação de enxertia. O LP e o LCP, entretanto, têm menor quantidade de elastina, conseqüentemente alongam-se menos quando submetidos a tração. Esta força de tração seria transmitida diretamente a todos os feixes de fibras colágenas e uma vez alcançada a sua capacidade de resistência, tanto o LP como o LCP rompem-se em um ponto, mantendo íntegra a estrutura dos colágenos restantes do ligamento. Talvez por apresentarem este tipo de ruptura, mostram bons resultados quando submetidos à sutura primária ${ }^{(10)}$. is true that the total resistance and elasticity of a ligament depend not only on the quantity of elastic fibrous elements in relation to collagenous fibers, but also on their arrangement and size and thickness of a ligament, as a whole. The results of the present study seem to agree with what one would expect for the three types of ligaments involved. The $P L$, as the distal part of the extension mechanism of the knee, serves to transmit all the force of traction of the quadriceps, received by the patella, to the anterior tuberosity of the tibia. Thus, the less its elasticity, the greater its efficiency in the transmission of traction force of the quadriceps. The PCL is considered the primary posterior stabilizer of the knee, and the basic stabilizer of the knee, due to its proximity to the center of rotation ${ }^{(3,9)}$. In order to do this job, it cannot permit excessive stretching, which confirms the findings of a smaller quantity of fibrous components containing elastin in this ligament.

The ACL is stretched by contraction of the quadriceps, in the hyperextension of the knee and internal and external rotation movements of the tibia in relation to the femur ${ }^{(14)}$. It can be seen that the ACL is involved in active movement, stretching and contracting with the anterior movement of the tibia in relation to the femur, which occurs depending on the contraction of the quadriceps in the extension of the knee. It also acts to dissipate the rotational force to which the knee is submitted. For the ligament to perform these tasks efficiently, it must have sufficient elasticity, which is provided by a greater quantity of elastin-containing fibrous elements. We could imagine that the closer to the original structure the composition is, the more quickly and efficiently the process of graft will be. Thus, in relation to elastic fibers, the $P L$ would be a better substitute for the $P C L$ than for the $A C L$, regarding graft reconstruction.

We suppose that the greater elasticity of the ACL may explain why its rupture leads to changes in the arrangement of the collagen bundles, reducing its capacity for healing. So, this is the case of an indication for grafting. The PL and PCL, however, have a smaller quantity of elastin, and consequently stretch little when submitted to traction. Traction force is thus transmitted directly to all the bundles of collagenous fibers and, once the capacity for resistance is reached, the ligament can stretch no further; both the $P L$ and the $P C L$ rupture at a single point, with the remaining structure of the collagens in the ligament maintaining its integrity. Perhaps due to this type of rupture, the patellar tendon is quite responsive to primary suture ${ }^{(10)}$. 


\section{REFERÊNCIAS}

1. ARNOCZKY, S.P. 1983 Anatomy of the anterior cruciate ligament. Clin. Orthop.172: 19-25,

2. BUCKWALTER, J. A.; COOPER, R. R.; MAYNARD, J. A. 1976 Elastic fibers in human intervertebral discs. J. Bone Joint Surg. [Am] 58: 73-76.

3. BUTLER, D. L.; NOYES, F. R.; GROOD, E. S. 1980 Ligamentous restraints to anetrior-posterior drawer in the human knee:a biomechanical study. J. Bone Joint Surg. [Am] 62: 259-270.

4. CLANCY, W. G. Jr.; SHELBOURNE, K. D.; ZOELLNER, G. B.; KEENE, J. S.; REIDER, B.; ROSEMBERG, T. D. 1983 Treatment of knee joint instability secondary to the rupture of the posterior criciate ligament. J. Bone Joint Surg. [Am.] 65: 310-322.

5. DANYLCHUK, K.D.; FINLAY, J. B.; KRCEK, J. P. 1978 Microstructural organization of human and bovine cruciate ligament. Clin. Orthop. 131: 294-298.

6. FRANK, C.; AMIEL, D.; ING, D.; WOO, S.L.Y.; AKESON, W. 1985 Normal ligament properties and ligament healing. Clin. Orthop. 196: 15-25.

7. FULLMER, H.M.; LILLIE, R.D. 1958 The oxitalan fiber: a previouly undescribed connective tissue fiber. J. Histochem. Cytochem. 6: 425-430.

8. GAWLIK, Z. Morphological and morphochemical properties ofthe elastic system in the motor organ of man. 1965 Folia Histochem. Cytochem. 3: 233-251.

9. GIRGIS, F.G.; MARSHAL, J. L.; AL MONAJEM, A.R.S. 1975 The cruciate ligaments of the kneejoint: anatomical, functional and experimental analysis J. Bone Joint Surg. [Am] 106: 216-231.

10. HUGSTON, J.C. 1993 Knee ligaments: injurie and repair. St. Louis, Mosby, pp.3-70.

11. IPPOLITTO, E.; ISHII, Y.; PONSETI, I. V. 1980 Histologic, histochemical, and ultrastructural studies of the hip joint apsule and ligamentum teres in congenital dislocation of the hip. Clin. Orthop. 146: 246-258.

12. JONES, K.G. 1963 Reconstruction of the anterior cruciate ligament: a technique using the central one-third of the patellar ligament. J. Bone Joint Surg. [Am.] 45: 925-932.

13. KENNEDY, J. C.; HAWKINS, R. J.; WILLIS, R. B.; DANYLCHUK, K. D. 1976 Tension studies of human knee ligaments. J. Bone Joint Surg. [Am] . 58: 350-355.

14. KUROSAWA, H.; YAMAKOSHI, K.I.; YASUDA, K.; SASAKI, T. 1991 Simultaneous measurement of changes in lenght of the cruciate ligaments during knee motion. Clin. Orthop. 265: 233-240.

15. NEURATH, M.; STOFFT, E.; ZSCHABITZ, A.; PRINTZ, H. 1991 Comparative microstructural studies on colllagen and elastic fiber systems of the cruciate ligaments. Z. Unfallchir. Versicherungsmed., 84: $170-176$

16. NIEWOHNER, D.E.; KLEINERMAN, J. 1977 Mophometric study of elastic fibers is normal and emphysemaetosus human lungs. Am. Ver. Resp. Dis. V:115 15-21.

17. RODRIGUES, CJ, JCL SACHETTI, AJ RODRIGUES JUNIOR. 1999b Age-related changes in the elastic fiber network of human splenic capsule. Lynmphology (in publication)

18. RODRIGUES JUNIOR, A.J.; TOLOSA, E.M.C.; CARVALHO, C.A.F. 1990 Electron microscopic study on the elastic and elastic related fibers in the human fascia transversalis at different ages. Gegenbaurs Morphol. Jahrb. 136: 645-652.

19. ROSEMBLOOM, J.; ABRAMS, W.R.; MECHAM, R. 1993 Extracellular matrix 4: the elastic fiber. FASEB 7: 1208-1218.

20. SALDINGER, R.; DVORAK, J.; RAHN, B. A., PERREN, S. M. 1990 Histology of the alar and transverse ligaments. Spine 15: 257-261. 